\title{
An Empirical Research on Shinepukur Holdings Ltd: Strategy, Accounting, Ratio, Sensitivity and Prospective Analysis
}

\begin{abstract}
K. M. Anwarul Islam ${ }^{1}$
${ }^{1}$ Department of Business Administration, The Millennium University, Dhaka, Bangladesh

Correspondence: Department of Business Administration, The Millennium University, Dhaka, Bangladesh, E-mail: ai419bankingdu@gmail.com

Received: October 03, 2017

Accepted: October 17, 2017

Online Published: October 30, 2017

Abstract

This paper examines how Shinepukur holdings ltd is going well or not? The major operations of the company are related to the development of lands and building apartments. Its operating performance is now going down because of the inefficient strategy formulation. The company cannot use its resources in full swings. Real estate customers purchase land or apartments on credit. Sometimes they fail to pay with in due time. Identifying the projects which customers will pay their credit within short term is important in this business. This policy is not followed by shinepukur. Moreover Managers had taken some unprofitable projects which brought negative return for the company. The company's core businesses are Apartment project and Land project. Competition in real estate industry is increasing day by day. After du-point analysis, we have found that company's performance is very much sensitive to its profit margin. In the valuation part we have found the company's present of equity per share is negative where share market price is 28.50 taka in the last trading day of 2015. This figure indicates market price of share is overvalued. Investors should not buy this company's share. In prospectus analysis we have made forecast for next three years income statement, balance sheet, cash flow statement on the basis of common size statement analysis.
\end{abstract}

Keywords: Strategy Analysis, Accounting Analysis, Ratio Analysis, Sensitivity Analysis, Prospective Analysis.

\section{Introduction}

Shinepukur holdings belong to SERVICE industry. It was incorporated in 1979 in the name of SHINEPUKUR JUTE SPINNERS LTD. In 1995 the company extends its business in real estate business. In this report we have analyzed the performance of real estate business operated by shinepukur holdings ltd. The company develops land and builds apartments, shopping malls and office complex for sale. It also deals in land.

\section{Literature Review}

In this article, Thachappilly (2009a) discusses Financial Ratio Analysis and its use for Performance Evaluation. There is typically a goal in doing business analysis: the need to make sense of the extremely large amounts of numbers shown in corporate financial statements. 
An Empirical Research on Shinepukur Holdings Ltd: Strategy, Accounting, Ratio, Sensitivity and Prospective Analysis

It's meant to be a tool to help investors judge the success of a firm, so that they can make an investment decision. These examples show us how we can analyze different kinds of ratios using different methods on diverse subjects like profitability, liquidity, debt, performance, and investment appraisal.

Thachappilly (2009b) is focused on talking about the Profitability Ratios Measures such as gross, operating, pretax, and net profits, as well as the return on assets, ROA ratio, ROE ratio, and ROCE ratio. While making this determination, he ascertains that the Gross profit is the profit earned by the sales value of products over the costs of items sold. In other words, he's saying he was talking about gross profit margin: gross profit/net sales or revenue. $R \& D$ and marketing expenses are deducted from gross margin to arrive at operating profits.

Jenkins (2009) came on strong, a better picture of a company's financial outlook can be obtained through the proper application of financial ratios and procedures. His belief is that fixed cost and variable cost are the most essential factors. Fixed costs are those costs that are always present, regardless of the amount of product or service sold. The costs that do not change are called fixed costs. These can include rent, insurance, and personnel pay. Variable costs include expenses that rise or fall depending on sales volume.

Nursing researcher Colaizzi's (1978) method of descriptive phenomenological data analysis. Method: To illustrate Colaizzi's process of extraction, organization, and analysis, an actual research study using the Colaizzi method was employed.

Some statistical discussions use causal analysis jargon, which goes back to Rubin (1974). The ideas themselves are fairly simple. In the absence of randomization, observational studies seek to discover how a certain factor impacts a situation. Differences in the dependent variable cannot necessarily be attributed to the hypothesized cause, because the researcher is unable to randomly assign persons to smoke. Thus, in observational research, alternative procedures must be used to ensure that the two groups are comparable. Some of the standard procedures include regression and matching (covariance adjustment) (nonparametric covariance adjustment).

Is this literature of interest to those outside of political science? Or is it still too early to tell? Rosenbaum (2002) argues that research that look at treatments, interventions, or policies and their effects include studies that examine "treatments, interventions, or policies" and that look at the absence of treatment.

\section{Strategy Analysis}

Under this topic we have focused on the real estate industry, Shinepukur's business strategy, competitive strategy and corporate strategy analysis.

\subsection{Industry Analysis}

Analysis of Porter's five factors:

\section{Force 1: Rivalry Among Existing Firms: It reduces the profitability of an industry.}

(i) Industry growth rate: service is a high growth industry. Demand of the products of this industry is increasing day by day. Number of Peoples with high level income is increasing and they are choosing product of this industry. This growth is not stagnant. So the industry is profitable.

(ii) Concentration and balance of components: Eastern housing is the leader of this industry. But now there are many private firms in this industry. They invest a large amount of capital in this industry. Their brand names are also recognized by the customers. The type of competition among firms is not limited to only price but also in the area of product quality, location of the product, handling time, land acquisition rate and credit facility. 
An Empirical Research on Shinepukur Holdings Ltd: Strategy, Accounting, Ratio, Sensitivity and Prospective Analysis

(iii) Degree of differentiation and switching cost: customers of this industry mainly focus on two things 1) position of the product 2) price of the product.

Product of this industry is highly differentiated. For example: a customer firstly goes to search for the length of the product like 1200square feet, 1800square feet or number of rooms. Then he searches for the location of the plat; gulshan, danmondy etc. and after it price of plat comes on. The switching cost for the customers is high in this industry. For example price of 1200square feet and 1500square feet is very different and the price does not vary too much in different firms for 1200 square feet product in the same location. So price competition is less in this industry for high switching cost.

(iv) Excess capacity and exit barriers: capacity of service industry is large than the customers demand. So firms cut price to fill the capacity. Firms main inputs are land, raw materials, human capital etc. Assets of firms are not too much specialized. So any firm can easily go out of this industry.

Force 2: Threat Of New Entrants: The new entrant in service industry is very much easy. It reduces the total profitability of the industry.

(i) Economics of scale: the economics of scale is not high for this industry. Some private firms like NAVANA or ASSET DEVELOPMENT companies acquire a piece of land and construct an office building, shopping mall or flat.

On the other side some companies like AL AMIN GROUP or EASTERN HOUSING acquire a large area and sale as plot. The economics of scale is not much more different for these two kinds of firms.

There are already 220 firms listed in REHAB within some years. This increasing rate of registration is a direct threat to our company SHINEPUKUR HOLDINGS.

(ii) First mover advantage: eastern housing is the first player in service business. It earned a large amount of profit in the first several years. Now there are five public and 218 private companies under this industry.

(iii) Legal barriers: some legal restrictions are preventing the profitability of this industry. One of the major barriers is that government has forbidden building on low land after restructuring the land. This barrier hampered the business very much. Because outside the city area many vacant lands are low. The only way to build a structure on this low land is by filling the land. If the rule is unchanged the profitability of this sector will go down with in some years.

Force 3: Threat of Substitute Products: in housing business the meaning of substitute is to build building, office or home individually. If the price or location is not attractive to the individuals, then he can purchase a land and build a building and rent the building for any type of use. The substitute product to a flat customer is to live in a rented house.

\section{Force 4: Bargaining Power of Buyers:}

(i) Price sensitive: buyers of this industry are not too much price sensitive because the product is differentiated by location like Gulshan, Uttara the price of the product in two different location must be different and customer are careful about it. The switching cost is high for this industry.

(ii) Relative bargaining power: there are many development firms in the housing business. And the number of customers also significant. In reality the bargaining power of customers is low because industry's product prices are not two much different among existing firms. Customers are not interested to substitute product (building own building) because it is difficult in our country's situation. To get a pure land and a developed land with 
An Empirical Research on Shinepukur Holdings Ltd: Strategy, Accounting, Ratio, Sensitivity and Prospective Analysis

communication. The facilities given by firms are more attractive to customers rather than build an own building. Communication facility, security system, drains facility and payment system is better if the product is bought from a reputed firm of this industry. So the bargaining power of customers is low.

Force 5: Bargaining Power of Suppliers: there are three factors of production in housing industry. a) Land b) Raw Materials c) Intellectual persons. In case of land bargaining power of suppliers is high, because there are many buyers for land. Bargaini ng power of suppliers of raw materials is low in some cases and high in some other cases.

(i) The threat of substitute product is the main critical factor for the profitability of this Service industry. Because the substitute of real state product is not so attractive to customers. The substitute means individually building home on purchased land.

(ii) Yes, the industry is capable of retaining the profit it has been making if the price is reasonable to the customers and if the players of this industry diversify its credit facility.

\subsection{Competitive Strategy Analysis}

At the present time Shinepukur holdings ltd. is loosing its growth of profitability because of unstructured strategy. There are two main strategies existing in the market. One is cost leadership by supplying same product at low cost, economics of scale and efficient production design. Second is product diversification by supplying a unique product, more flexible delivery, investing in brand image, investing in research and creativity.

Shinepukur may not survive or prosper in its given strategy because its product is not unique or differentiated from the market product and it couldn't achieve the cost leadership in production. The main reason of this failure of the company is that it didn't concentrate in real state business alone it also concentrating in just business. Shinepukur should change its strategy to operate the real state and jute business by with a single entity. It should achieve cost leadership in the real state business. And should focus on only one business like real state business. It should increase investment in brand image. These activities can only make it profitable in service industry.

\subsection{Corporate Strategy Analysis}

Shinepukur holdings ltd. operates jute, real estate and ceramic business. It is also thinking to involve in hotel business. It holds different strategies for different sectors. But the main strategy is to simultaneously operate unrelated businesses.

\section{Investment}

- Shinepukur holdings ltd. Invests 85.682 million taka in international holdings ltd, 2 million taka in international cement ltd,

- 4 million in shinepukur hotels ltd,

- 180.2 million taka in Beximco ltd, 1 million taka in CDBL.

\section{Hotel Project}

Company is planning to build a hotel in front of hotel Sheraton. The project is under government observation. 
An Empirical Research on Shinepukur Holdings Ltd: Strategy, Accounting, Ratio, Sensitivity and Prospective Analysis

\section{Cement Factory}

The progress of this project is now stop because of volatile market makes it extremely risky to invest in this sector at this moment.

\section{Employees' Relations}

The management- employee relations in our company remained supportive of production and conducive to the growth of the company during the year.

\section{Accounting Analysis}

Step: 1: Key Accounting Policies of Shinepukur Holdings Ltd.

Financial statement preparation: financial statements of shinepukur holdings ltd are prepared under the historical cost convention.

Revenue recognition: revenue is recognized on accrual basis.

Valuation of property plant and equipment: the cost of acquisition of an asset comprises its purchase price and any directly attributable cost of bringing the asset to its working condition for its intended use inclusive of inward freight, duties and non- refundable taxes.

Depreciation on property plant and equipment:

Office equipment $\quad 15 \%$

Transport and vehicle $\quad 10 \%$

Furniture and fixtures $\quad 10 \%$

Sundry assets $\quad 20 \%$

\section{Inventory treatment}

Inventories are stated at the lower of cost and net realizable value. The cost is calculated on weighted average method consistently. Net realizable value is based on estimated selling price less any further costs expected to be incurred to make the sale.

Taxation: both current tax and deferred tax has been provided. $201135 \%$

2012. $.30 \%$

2013. $.30 \%$

2014 $.30 \%$

2015 $.30 \%$

\section{Leases}

Assets leased under agreements qualifying as operating lease. Hence, lease rentals are expensed as incurred.

\section{Borrowing cost}

Interest and other costs incurred by the company in connection with the borrowing of funds are recognized as an expense in the period in which they are incurred unless activities that are necessary to prepare the qualifying asset for its intended use are in progress. 
An Empirical Research on Shinepukur Holdings Ltd: Strategy, Accounting, Ratio, Sensitivity and Prospective Analysis

\section{Step 2: Assess accounting flexibility}

The existing accounting policies and estimates of Shinepukur holdings ltd are not informative enough for the investors to take the decision to invest in this company. Accounting personals have the flexibility to change the estimate in inventory, depreciation; profit participation fund, dividend payment etc. but sudden change in these factors can reach wrong information to its shareholders.

\section{Step 3: Evaluate Accounting Strategy}

The company is following the rules as adopted by the institute of chartered accountants of Bangladesh. It is following conservative accounting strategy for revenue and liability recognition.

\section{Step: 4: Evaluate The Quality Of Disclosure}

The quality of disclosure of Shinepukur holdings ltd is moderate. It should disclosure some items more clearly to understand the real position of the company's operation. Managers should give more attention in this area.

\section{Step 5: Potential Red Flags}

- The interpretation of inter unit loan has not been given properly.

- Purchase and disposal of fixed assets should be explained more clearly.

- Company is not paying dividends.

- Earning per share is very low in the last year.

\section{Ratio Analysis \\ Internal Liquidity Ratio}

Current ratio: The time series analysis of current ratio is showing that the ratio has a declining trend. It means that the company's ability to meet up the current obligation is declining year by year.

The reasons behind this decline are as follows

- Decrease in advance income tax paid

- Decrease in inventory for low production

- High growth in accrued expenses

- Current Maturity of long term debt

- Liability due to associated undertaking

Quick ratio: After deducting the inventory from the current assets we have found these quick ratios for the last four years. This is also showing a declining trend. It means that the sensitivity of inventory change is not important to the company.

Inventory turnover: The inventory turnover ratio for the last four years is almost stable. The companies can make strong

Advertisement and price discount to make low its inventory.

Average collection period: The average collection period for the company of the last four years is gradually increasing. There may be two reasons behind this increase. The first one is that company is enhancing its credit policy. It is giving more times to its customers for payments. Second reason is the adverse selection of the customers.

- The company's accounts receivable is increasing year by year where sales are decreasing. 
An Empirical Research on Shinepukur Holdings Ltd: Strategy, Accounting, Ratio, Sensitivity and Prospective Analysis

- Real estate business faces the risk of default by customer. Customers pay a down payment at the beginning of the contract and after it rest amount is paid in installments. For this reason average collection period is longer.

- Shinepukur holdings should impose low interest rate for early payment to speed up the collection period.

\section{Operating Efficiency Ratio}

Fixed asset turnover: The average turnover of sales on fixed asset of Shinepukur holdings ltd for the last four years is around 2.55. This turnover indicates amount of taka sales to per taka fixed assets.

Total asset turnover: The average turnover of sales on total assets of this company for the last four years is around 0.20 . The company is using huge amount of current assets in its operation. It means that company's one taka asset generating 0.20 tk sales.

\section{Financial Risk Ratio}

Debt ratio: The Company's current debt ratio is 0.34 . This ratio is increasing which means that the company is using more leverage in its operation.

Debt to equity ratio: Debt to equity ratio measures the financial risk that the company bears. The current debt to equity ratio is

0.22. It means that the company's financial risk is low. It is using more equity in its capital structure.

- The company's long term debt is reduced by $23.17 \%$ in last 4 years.

- Equity increased by $8.57 \%$ in last 4 years.

Time interest earned: the Company's current interest earning ratio is 1.02 which is decreasing year by year. This indicates that the company's ability to pay fixed interest rate is going down. This a major red flag for the company.

- In this situation, Shinepukur should reduce its fixed interest bearing debt.

\section{Operating Profitability Ratio}

Gross profit margin: The company's gross profit margin is increasing but at a slow rate. Cost of goods sold per one taka sale is being reduced last 2 years. This is happened for efficiently managed the raw material procurement.

Operating profit margin: After deducting the operating expenses we get operating profit margin. The company's operating profit margin is not changing significantly due to the unchanged administrative and selling expenses.

Net profit margin: The Company's current net profit margin is $0.45 \%$ which is one third of the previous year.

- Low difference between EBITDA and interest expense is the reason for this low profit margin.

ROA: In the current income year, 2015 the return on assets has declined at a high rate.

- Since Shinepukur last year's profit margin was low, return on asset was also low in that year.

- Low ROA means that the assets of Shinepukur are not being using efficiently. 
An Empirical Research on Shinepukur Holdings Ltd: Strategy, Accounting, Ratio, Sensitivity and Prospective Analysis

- Unproductive assets should sell out.

ROE: The ROE is the most significant parameter to measure a company's operating performance. Since we have used a large portion of equity as our source of fund and generate low return, the company's return on equity is lower in the year 2015.

- ROE can be inflated by boosting net profit in discretionary methods.

EPS: Since the ROE has declined the earning per share has also declined.

- The number of shares increased by 200000 in 2015, when the generated of net profit is low.

\section{Price/ earnings ratio}

The company's recent $\mathrm{P} / \mathrm{E}$ ratio is 246.28 because of the low earning. Our company's market to price earnings ratio is higher in last 4 accounting year. Share price of Shinepukur holding is declining for the bad performance of the company.

\section{Sensitivity Analysis}

\section{Sensitivity to Profit Margin}

ROE is highly sensitive to the changes in the changes in profit margin. We see that the dispersion is $114.65 \%$. that is if there is any change in net earnings, ROE is significantly changed.

\section{Sensitivity to Asset Turnover}

Now the average change in ROE due to change in asset turnover is $-7.68 \%$ and the dispersion is $10.12 \%$.So ROE is also sensitive to asset turnover over the period, but this volatility is not as high as it is in case of profit margin change.

\section{Sensitivity to Leverage}

ROE is least sensitive to the leverage ratio. The average change is .33\%, whereas the dispersion is $3.74 \%$

\section{Prospective Analysis}

\section{Valuation of Shinepukur Holdings Itd}

The enterprise value of the firm is 857504234 taka and the equity value is -322659191 taka. The firm has a total of 22500000 shares outstanding with a per value of 100 taka per share. The market value per share of the firm is 28.5 taka, which is the market value of the share price of the firm at the last date of 2015. The market overvalues the firm because through our analysis and DCF calculation we find out that the share price should be -1.5 taka only. The company has not been paying any dividend in last some years. So the investors expecting that the company share will be decrease in near future.

Apart from the DCF valuation model, the probability ratios of the firm further affirms the fact the investors should not put their faith in the firm and have no confidence in it.

\section{Assumptions}

- Sales will grow up at a rate of $-4 \%$ in the future.

- COGS will grow up at a $-4 \%$ rate since the company is inventing cost saving formula.

" Depreciation rate charged ore capital xpenditure was $10 \%$. 
An Empirical Research on Shinepukur Holdings Ltd: Strategy, Accounting, Ratio, Sensitivity and Prospective Analysis

" It is assumed that the company's inventory will be increased by $6 \%$ in future.

- Accounts receivable will be increased by $6 \%$

- Other current assets will be decreased by $-4 \%$ in the succeeding years.

- Marginal tax rate is $30 \%$

- Terminal growth rate is $2 \%$

" Accrued liability will grow down at a rate of $20 \%$.

- The cost of equity is $16.5 \%$

- Cost of debt before tax is $12.26 \%$

" WACC is $16.5 \%$

- Beta of the company is 1.122

- $\quad$ Risk free rate is $7 \%$

- Market return is $27 \%$

" The DCF calculation is done using the perpetuity method

In pro-forma analysis we have forecasted for 2015 and 2016 based on average ratio of individual items to sales of previous three years. Some assumptions also have been taken to predict the future value. Based on this assumption the accounting figures that we have got are as follows

\begin{tabular}{|l|l|l|}
\hline ITEMS & 2015 & 2016 \\
\hline NET INCOME & $17,033,194$ (taka) & $39,393,082$ (taka) \\
\hline GROSS PROFIT & $153,956,283$ & $147,798,031$ \\
\hline CURRENT ASSETS & $3,712,226,061$ & $3,742,245,347$ \\
\hline TOTAL ASSETS & $3,962,592,235$ & $3,982,137,566$ \\
\hline CURRENT LIABILITIES & $496,190,632$ & $476,343,007$ \\
\hline TOTAL LIABILITIES & $1,129,875,858$ & $1,110,028,108$ \\
\hline EQUITY & $2,832,716,377$ & $2,872,109,458$ \\
\hline NEW FUNDING & $(0)$ & $(0)$ \\
\hline LONG TERM DEBT & $633,685,226$ & $633,685,101$ \\
\hline
\end{tabular}

Assumptions:

- Sales growth is $-4 \%$

- Inventory is $281.32 \%$ of sales

- COGS is $75.28 \%$

- Average Income tax rate is $21.79 \%$

" Cash is $0.68 \%$ of sales of that year

- Accounts receivable is $47.53 \%$

- Accounts payable is $13.63 \%$

" Effective interest rate is $12.42 \%$

- Dividend payout ratio is $0 \%$ of net income

" advance income tax payment is $0.11 \%$

- $\quad$ Accrued expense is $9.23 \%$ 
An Empirical Research on Shinepukur Holdings Ltd: Strategy, Accounting, Ratio, Sensitivity and Prospective Analysis

\section{Conclusion}

The result of financial and pro-forma analysis of Shinepukur Holdings ltd inform us that the company is not performing well. It is now losing its position in service industry. The company is now taking initiatives to expend its area of business. Within some days it will start cement and hotel business. Since the company has a moderate band image in the market investors expect that the company will successfully face and retrieve all the financial distortions in the future day.

\section{References}

Annual Reports, 2007-2016. Shinepukur Holdings Ltd.

Colaizzi, P. (1978). Psychological research as a phenomenologist views it. In: Valle, R. S. \& King, M. (1978). Existential Phenomenological Alternatives for Psychology. Open University Press: New York.

Jenkins, L. (2009). Contribution Margin and Breakeven Analysis: Determining when a Company will Realize a Profit. Journal of contribution margin and breakeven analysis, 8, 65-83.

Thachappilly, G. (2009a). Profitability Ratios Measure Margins and Returns: Profit Ratios Work with Gross, Operating, Pretax and Net Profits". Journal of profitability ratio measure margin and return.

Thachappilly, G. (2009). Financial Ratio Analysis for Performance Check: Financial Statement Analysis with Ratios Can Reveal Problem Areas. Journal of financial ratio analysis for performance evaluation.

Rubin, D. B. (1974). Estimating causal effects of treatments in randomized and nonrandomized studies. Journal of educational Psychology, 66(5), 688.

Rosenbaum, P. R. (2002). Overt bias in observational studies. In Observational studies (pp. 71-104). Springer, New York, NY.

http://www.shinepukur.com/ Retrieved May 01, 2017

\section{Copyrights}

Copyright for this article is retained by the author(s), with first publication rights granted to the journal. 